\title{
Crime in São Paulo's metro system: sexual crimes against women
}

\author{
Vania Ceccato ${ }^{1} \cdot$ Yuri Paz
}

(C) Macmillan Publishers Ltd 2017

\begin{abstract}
The article investigates personal safety conditions in the São Paulo metro, the largest rapid transit system in Brazil. The study looks at all types of crimes, but devotes special attention to the nature and spatio-temporal dynamics of sexual crimes against women while in transit. The methodology combines Geographical Information System and crime records with data collected using Google Street View and other secondary data into a set of regression models. Findings show that sexual violence is concentrated at the busiest central stations; it often takes place during the morning and afternoon rush hours, and at stations that also attract all sorts of violence and events of public disorder. The study finalises with an analysis of the metro's current prevention practices targeting women's sexual victimisation.
\end{abstract}

Keywords Gendered violence · Subway · Transit environments · GIS · Google Street View

\section{Introduction}

I turned around and saw my whole leg soiled. He was closing the zipper of his pants. I despaired and started screaming for help. I was rescued by other passengers, while others held the assailant in the carriage...After this, I did not want to take that route anymore...I decided to go to court against the metro, asking for compensation (young woman on the way to work).

Vania Ceccato

vania.ceccato@abe.kth.se

1 Department of Urban Planning and Environment, School of Architecture and the Built Environment, KTH Royal Institute of Technology, Drottning Kristinas väg 30,

10044 Stockholm, Sweden 
Cases as the one above happen every day in the São Paulo metro. A recent survey shows that two of three women declared being victims of sexual harassment and violence while in transit, half of them on public transportation, while the proportion among men is 18\% (Datafolha 2014). Yet, the majority of cases go underreported. Similarly, in England and Wales, sexual assault and harassment are generally underreported (for a review, see Gekoski et al. 2015), with estimates of 75-95\% of victims never reporting incidents to the police. Women are ashamed and even if they want to report, they declare finding it difficult to do so for different reasons. In spite of considerable media attention to the problem (Araújo 2016; JC 2016), the exact nature, location and time of these offences against women remain unknown. The lack of research on women's transit safety is not exclusive to Brazil, but it is a more general problem found elsewhere as well (Can 1995; Gekoski et al. 2015; Madan and Nalla 2015; Natarajan 2016; Seedat et al. 2006; Sham et al. 2013).

This article aims at contributing to this area of research by assessing the nature, the levels and the patterns of sexual crimes against women (cases of staring, touching, groping, ejaculation, exposing genitalia and full rape) in the São Paulo metro system, the largest rapid transit system in Brazil, and the second largest in South America. The analysis is performed by comparing reported data with records of other types of crimes in the subway system in time and space. The aim is achieved by (a) creating a Geographical Information Systems (GIS) database of incidents and attributes of subway stations, and demographics and socio-economic characteristics of the surrounding areas, using Google Street View; (b) assessing the relationship between incidents and attributes of underground stations and surrounding areas, with particular focus on women's sexual victimisation in transit; and (3) reporting and reflecting upon current crime intervention programmes targeting women's sexual victimisation in the metro system.

The novelty of this study is twofold. The analysis is based on a recently available data set from the metro company. Owing to a lack of data and their poor quality, there has been relatively little research interest in crime and disorder in transit environments in Brazil. This study makes use of aggregated reported data by type and station (2010-2015) obtained from the São Paulo metro company and by time (2013-2015) as well as aggregated data from an sms-service (2014-2015), which is a service to report crime and other incidents that happen during the trip and/or metro premises. Another novelty is the opportunity to explore Google Street View as a source of information, gathered using GIS, on the environmental features around the subway stations.

\section{Theoretical background and hypotheses of study}

\section{Crime and sexual victimisation in metro environments}

Crime does not happen in a vacuum; it reflects people's routine activities and daily, rhythmic habits. Transportation nodes, such as metro stations, are special places in this matter because they make daily routines happen, allowing the movement of people from $\mathrm{A}$ to $\mathrm{B}$, at the same time that they bring people together in transport 
nodes, converging in space and time. Most crimes depend on these interrelations in space and time: offenders' motivation, suitable targets and absence of responsible guardians, as suggested by routine activity theory (Cohen and Felson 1979). Transit environments are a fertile territory for sexual and other types of abuse and harassment. An empty train in the evening might just allow the anonymity that an offender needs to commit a rape (Ceccato et al. 2017; Gekoski et al. 2015; Hewitt and Beauregard 2014). Similarly, crowded rush hours might just provide the right opportunity for groping and all sorts of inappropriate unwanted sexual behaviours (Madan and Nalla 2015; Natarajan 2016). This is a particular problem in big cities in countries of Global South where the poor supply of public transportation means that women are relatively more exposed to sexual victimisation. Thus, it is expected that in São Paulo metro, sexual victimisation as well other transit offences follow crime-specific spatial and temporal patterns determined by the conditions of the transportation system, at particular hours of the day, days of the week and seasonally.

A metro station can be the place where offender and victim awareness spaces converge, a condition that may lead to crime. The vast majority of crime occurs within the offender's 'awareness and activity space' (Brantingham and Brantingham 1995), which means that crime place is often a familiar spot for both offender and victim. However, if, for any reason, an offender does not see the place as a target, or as part of her/his territory, crime will not happen. Even within this awareness space, the offender's judgment is influenced by multi-scale conditions at a particular place. These conditions are generated by stations' local environments (Ceccato 2013; Ceccato and Newton 2015; Ceccato et al. 2017; Levy et al. 2017; Loukaitou-Sideris 2012; Loukaitou-Sideris et al. 2002; Newman 1972; Uittenbogaard 2015) but also by the type of neighbourhood in which the station is located (Mustaine et al. 2006; Shaw and McKay 1942) as well as the relative position of both the station and the neighbourhood in an urban area. Thus, what happens in terms of crime and sexual victimisation in the São Paulo metro system is bound to be a function of the stations' local environments and the contexts in which stations are embedded (neighbourhood and city).

\section{Situational crime preventing sexual violence in transit environments}

One way to prevent crime is making it difficult to happen. Situational crime prevention focuses on methods to reduce crime opportunities (Clarke 1997). These strategies focus on changing the environment and how it is managed, thus closing off opportunities for crime. A key element in this approach is identifying the underlying drivers of a particular offence in time and in each particular environment.

The international literature is vast in showing how places can be made safer by applying situational crime prevention (LaVigne 1997; Levine et al. 1986; Newton et al. 2015), but it is much more limited in showing ways to prevent sexual violence against women in transit environments (Gekoski et al. 2015; Madan and Nalla 2015; Natarajan 2016; Natarajan et al. 2015). 
Common safety interventions may include design strategies (e.g. improving lighting, decreasing disruptive objects, increasing visibility, good maintenance of transport facilities, implementing real-time scheduling information), passenger separation strategies (e.g. women's only carriages/taxis, splitting passenger flows), improvement of surveillance (e.g. CCTV, presence of security officers, training of personnel and passengers to be alert and intervene, hotlines, implementation of emergency buttons in carriages, sms-services), targeting routes (hot spots known to have higher crime rates), raising awareness (campaigns to motivate individuals to report, organising public workshops, actions through social media in collaboration with existing campaigns used in raising awareness about sexual violence in public spaces, in particular, see Lea et al. 2017 in this Special Issue, including women's voices by using new technology and crowdsourced data). For an extensive review of common safety interventions to combat sexual violence, see Gekoski et al. (2015) covering evidence from the UK, Australia, New Zealand, USA and Denmark. In summary, these interventions vary in nature but they also share similarities: they often involve changes in the transit environment and implementation of new management routines. Our hypothesis is that also in São Paulo, crime prevention initiatives devoted to sexual victimisation, if any, are devoted to making passengers aware of the problem and empower victims to come forward.

\section{The present study}

\section{The study area}

The study area is composed of 62 stations in the São Paulo metro (Metropolitano de São Paulo), excluding some expansion (65 stations total), which is the main rapid transit system in the city of São Paulo, the largest in Brazil and the second largest system in South America. The system was founded in 1968 with one line, and today has five lines (74 km, see "Appendix 1") carrying 4,600,000 passengers per day on 154 trains operating from Sunday to Saturday, from 4:40 a.m. to midnight (1:00 a.m. on Saturdays). The Metro runs within São Paulo municipality-a municipality with 12 million inhabitants. Another company, São Paulo Metropolitan Train Company (CPTM), serves 22 municipalities that make up the São Paulo Metropolitan Region with a total of 21 million inhabitants, 258.4 km, 92 stations, and 2,900,000 passengers per day (Metrô 2015).

\section{Data and method}

This study makes use of data from Delpom (Delegacia de Polícia do Metropolitano) and Polícia Civil reported by passengers (2010-2015) obtained from São Metro company (aggregated by type and station) and by time (2013-2015) as well as from one sms-service (2014-2015), which is a service to report crime and other incidents that happen during the trip and/or metro premises. Crime incidents include property and violent crimes, such thefts, muggings and all sorts of violence, including sexual violence and sexual harassment. The sms-data involve minor incidents but can 
include crimes such as sexual violence, sexual harassment and groping, as well as non-crimes such as begging, noise, and incivilities like putting feet on metro benches and irregular commerce inside metro property. While crime incidents can be split by station, sms-data cannot. In order to standardise the levels of incidents, number of passengers was also obtained from Metro, which are estimates of number of passengers in a working day by station and peak and off-peak hours, as well as the total number of personnel (security and overall) by station.

There are on average 24 security guards per station, and although security guards rotate between stations, they tend to be concentrated at large stations: $73 \%$ of the stations lack permanent security guards. This fact is bound to have an effect on reporting practices of crime and disorder (both in total levels and geography) since passengers may be discouraged to report if personnel are not around (Ceccato 2013; Ceccato and Newton 2015; Newton et al. 2004). In the São Paulo system, there are indications of high reporting practices at larger stations. A significant correlation was found between total personnel by station and total reported events $(r=0.57$, $p=0.01$ ), as well as between total security guards and number of CCTVs ( $r=0.29, p=0.05)$, which indicates larger stations. If the incidents are witnessed by others, e.g. inside a carriage, the likelihood that the event is reported also increases (see Lea et al. 2017, in this Special Issue). Although coordinates were available for the station, it was not possible to know the precise location where the event occurred (during the trip, at the station, in the carriage, or on other nearby premises). The best indication was an estimation from the metro that about $40 \%$ of reported events took place on the train, inside the carriage.

The environment of metro stations follows some common standards, but they are far from homogeneous and greatly differ in security resources, which potentially impacts the stations' vulnerabilities to crime and disorder. In terms of CCTV, the average number of cameras per station is 19 , but they also tend to be located at the busiest hubs: $5 \%$ of the stations have 50 cameras or more.

In order to assess the influence of the surroundings on crime incidents at each station, a number of criminogenic land-use indicators were manually collected using Google Street View. Figure 1a illustrates the detailed level of the landscape collected about the environmental features and land use around the subway stations, and Fig. 1b shows the combined data set with other data on land use (e.g. existence of parking lots, restaurant/bars, banks and schools). These observations were later input into spreadsheets and then imported into GIS together with other data on land use, crime and demographic and socio-economic data on the population. Policerecorded data for the surroundings (from Secretaria de Segurança Pública de São Paulo, SSP) are used here as a reference. Stations and crimes were mapped as point data, whereas the São Paulo demographics and socio-economic data (from GeoSampa portal in 2016) were linked to small unit statistics around the stations. Whether stations were larger hubs was indicated by a dummy variable and distance from the station to the city centre, and also included in the model ("Appendix 2"). Interviews with personnel were performed in December 2015 to obtain information about crime prevention programmes, and in particular about sexual violence and current prevention measures. Documents and videos were obtained from the metro itself but also from material available in newspapers and on the internet. 


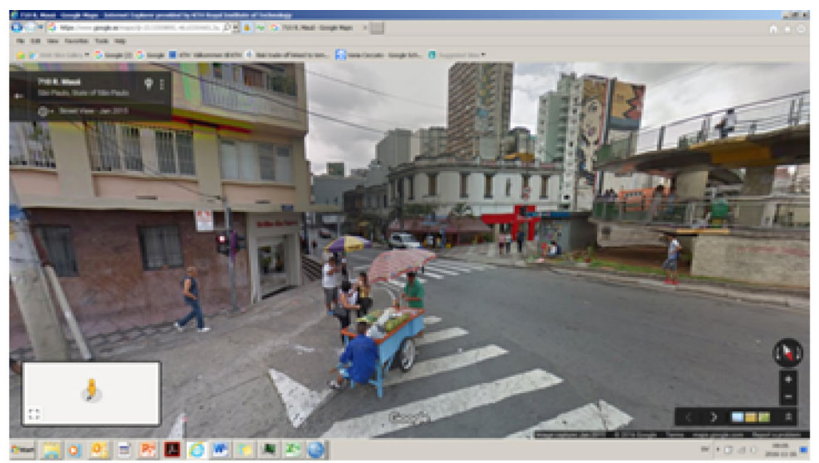

(a)

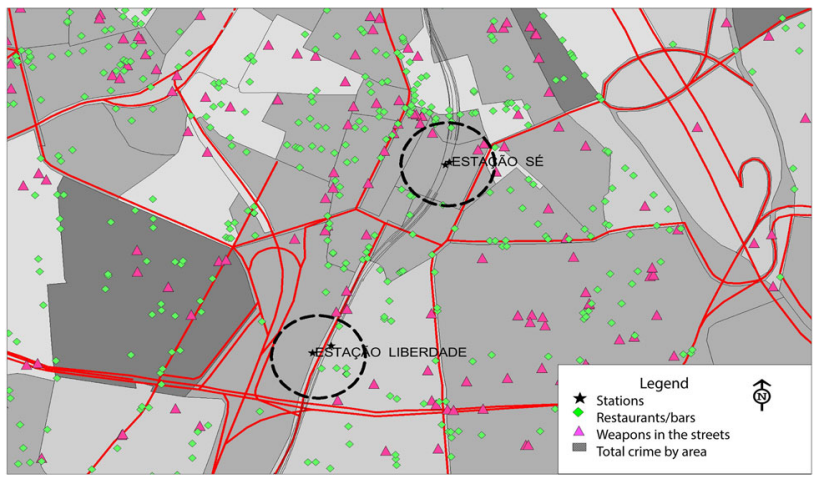

(b)

Fig. 1 a Stations' surroundings inspected using Google Street View; b stations locations and characteristics of the surroundings in GIS

Instead of using crude data of crime events by station, rates per 10,000 passengers were calculated based on the passenger flow at each station. The purpose was first to explain the variation in station-specific rates for various types of incidents and later compare them with those found for sexual harassment and/or sexual violence. The dependent variables are rates by passenger flow for selected offences from data of the station. The independent variables are a set of four factors which are the result of a factor analysis in SPSS of over 25 variables (for details see e.g. Costello and Osborne (2005)) characterising environmental attributes of the stations and demographic, socio-economic and land-use covariates of the surrounding areas following the conceptual model suggested by Ceccato (2013).

\section{Results}

\section{Sexual crimes against women and other crimes in the São Paulo metro}

A small share of cases of sexual harassment and/or sexual violence is reported in the São Paulo metro (Fig. 2a). Yet, it is believed that two-thirds of female passengers 

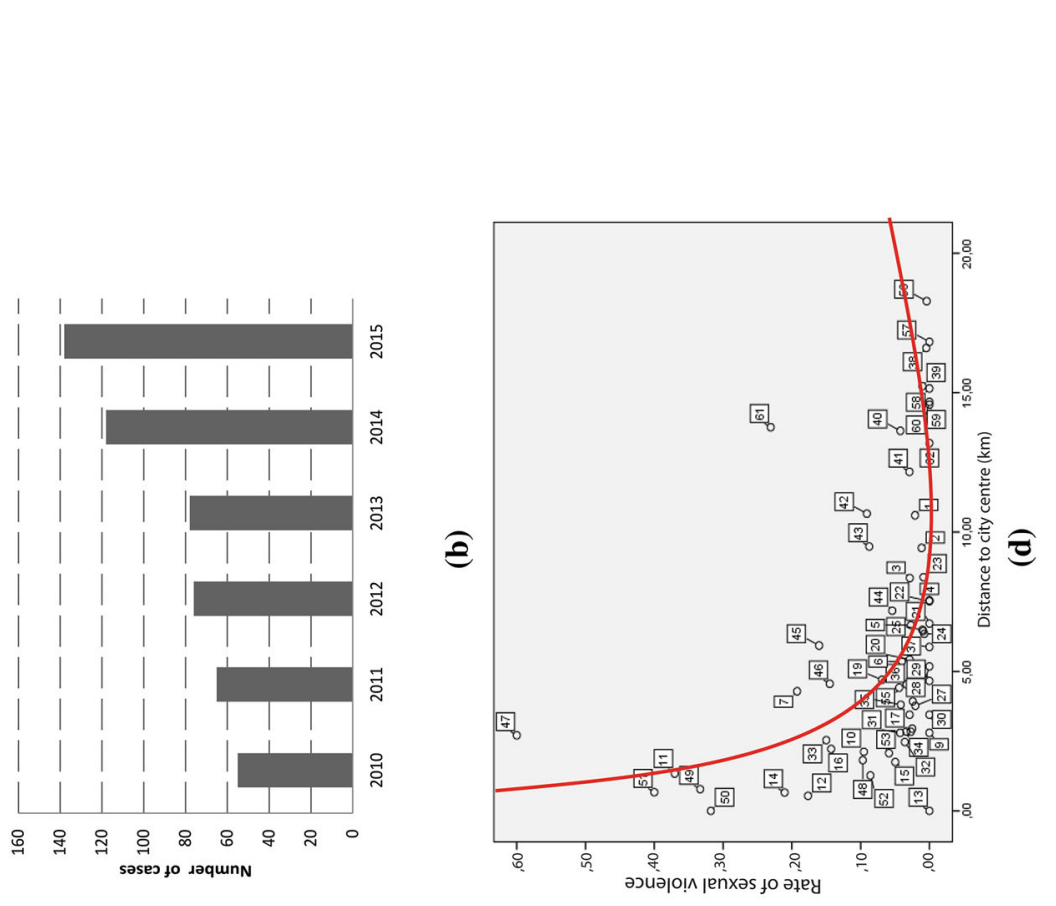

芯

s.

突

$\stackrel{Ð}{\rightleftarrows}$
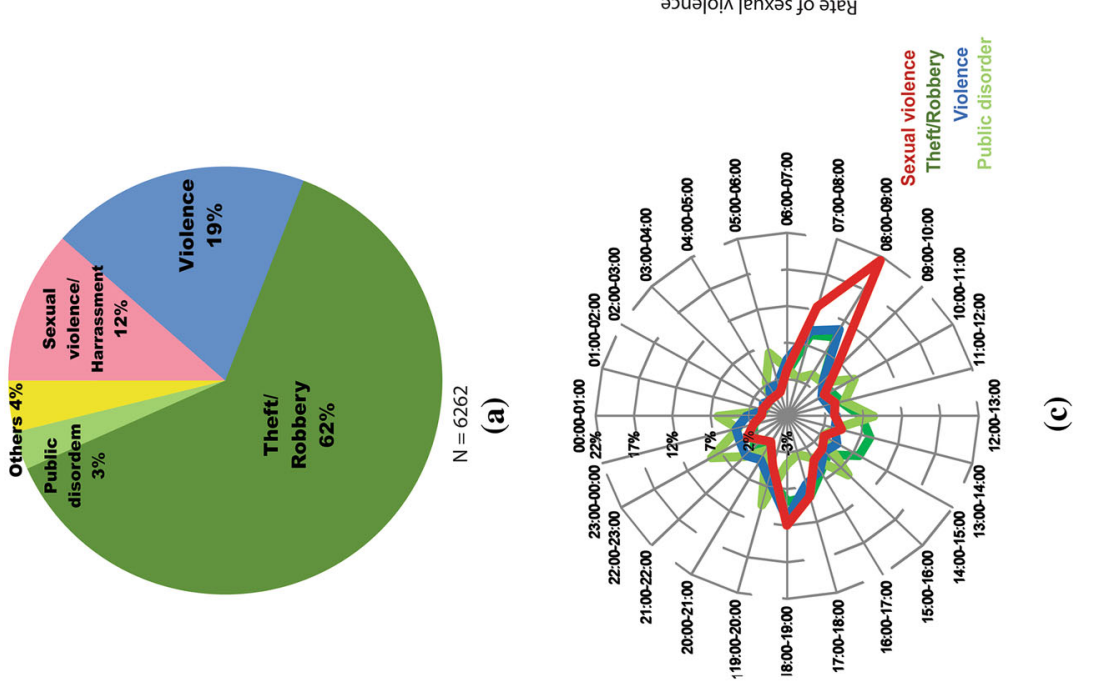
have experienced it (Datafolha 2014) and that it is on the rise (Araújo 2016; Souza and Valle 2017). From total reported crimes, $12 \%$ of incidents constitute cases of staring, touching, grouping, ejaculation, exposing genitalia and up to full rape. The crime category is the same but the reaction varies, as some women get stunned, others feel scared or traumatised, while others feel desperate. Despite a recent increase in reporting figures (Diógenes 2017), many cases go unreported because many women are ashamed to report or do not find metro personnel to record the incident. These underreporting figures should be kept in mind when interpreting the results in this study.

Figure 2a indicates that the large majority of reported incidents (62\%) is composed of property crimes such as thefts and robberies, and according to Valle and Bottini Filho (2014), mobile phones are a major target. Fights and other types of violence compose nearly a fifth of the records. Important to note is that there are other events that are also underrepresented in this data set (some of them are gathered elsewhere, e.g. via sms-service, and will not be discussed here), such as cases of physical damage against property, begging and other types of public disorder, which in many other transit system may constitute the large majority of recorded incidents. In Stockholm's metro system, only $15 \%$ of incidents are actually crime (Ceccato 2013).

Clear hot spots of sexual harassment and/or sexual violence emerge at stations of São Paulo's inner city. The highest numbers of cases are on the Red and Blue Lines: Sé station (with about half of the cases), Brás, Luz, Bresser-Mooca, Anhangabaú and Pedro II. In the most recent surveys, the Red Line is also pointed out by passengers as being more problematic, especially in terms of security, accessibility and comfort (Araújo 2016).

There are distinct peaks of recorded incidents of sexual harassment and/or sexual violence in the São Paulo metro that correspond to people's daily routine activities. Most of these events happen from Monday to Friday (20\% on Mondays and Tuesdays and only $6 \%$ on Saturdays) when people are going to or returning from work. The most significant peak in cases happens during rush hour in the morning, between 8:00 and 9:00, and in the late afternoon between 18:00 and 19:00 (Fig. 2c), also confirmed for 2016 data by Souza and Valle (2017), when the most trains and lines are overcrowded (note that trains run from 4:40 a.m. to midnight, and until 1:00 a.m. on Saturdays). There are slightly increases in the number of cases in June and July. However, a longer time series of data would be necessary to test differences in seasonal patterns. High rates of reporting are more often found at stations located within a $3 \mathrm{~km}$ radius from the city centre (Fig. 2d), following a distance decay distribution from Sé station. As Fig. 3a shows, transit overcrowding facilitates all sorts of incivilities and 'legitimate' inappropriate behaviour, not in the least sexual harassment and sexual violence in the São Paulo metro, an old problem that only recently has prompted passengers' protests (Fig. 3b).

\section{Modelling sexual crimes against women in transit}

Findings from modelling and factor analysis indicate that high rates of recorded sexual harassment and/or violence tend to be more common at more central stations (these stations have relatively large numbers of CCTVs and metro personnel, 


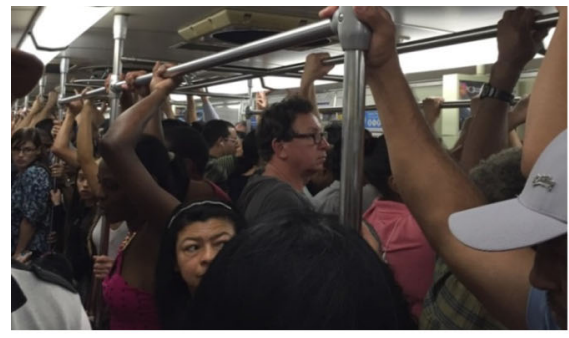

(a)

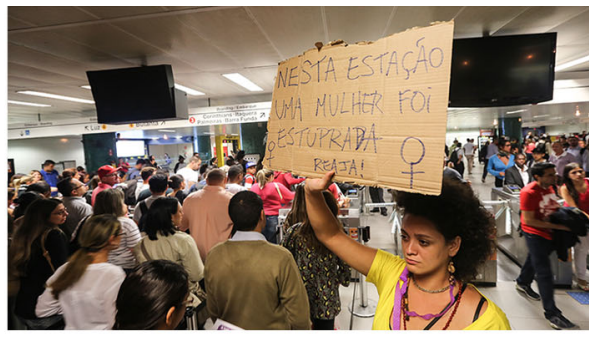

(b)

Fig. 3 a Overcrowding is a chronic problem at peak times in São Paulo metro. Source: Vania Ceccato 2016; b Campaigners sexual crimes against women in São Paulo metro: 'In this station a women was raped, React!'. Source: Julia Chequer

Table 1 Modelling results, OLS, Y = incidents per passengers flow 2013-2015

\begin{tabular}{|c|c|c|c|c|}
\hline & $\begin{array}{l}\text { Sexual } \\
\text { harassment/ } \\
\text { violence }\end{array}$ & Violence & Theft/robbery & Total crime \\
\hline $\begin{array}{l}\text { Factor } 1-\text { 'Big, central, } \\
\quad \text { trouble' }\end{array}$ & $0.028 *(1.994)$ & $0.00003(0.945)$ & $\begin{array}{l}0.0004 * * * \\
(2.102)\end{array}$ & $\begin{array}{r}0.004 * * * \\
(3.540)\end{array}$ \\
\hline $\begin{array}{l}\text { Factor } 2 \text { - 'End-line, visible, } \\
\text { poor' }\end{array}$ & $0.002(0.139)$ & $0.00004(0.100)$ & $\begin{array}{r}-0.0003 * * \\
(-1.695)\end{array}$ & $\begin{array}{r}-0.002 * * \\
(-2.068)\end{array}$ \\
\hline $\begin{array}{l}\text { Factor 3-'Small, accessible, } \\
\text { affluent' }\end{array}$ & $0.041 * * *(2.962)$ & $\begin{array}{l}0.000009 * * * \\
\quad(2.776)\end{array}$ & $\begin{array}{l}0.0003 * * * \\
(2.061)\end{array}$ & $\begin{array}{l}0.002 * * \\
(2.205)\end{array}$ \\
\hline $\begin{array}{l}\text { Factor } 4-\text { 'Open, transition, } \\
\text { shopping malls' }\end{array}$ & $\begin{array}{r}-0.031 * * \\
(-2.291)\end{array}$ & $\begin{array}{l}-0.000009 * * * \\
(-2.71)\end{array}$ & $\begin{array}{r}-0.000217 \\
(-1.195)\end{array}$ & $\begin{array}{l}-0.001 \\
\quad(-1.116)\end{array}$ \\
\hline$R$-square & .25 & .23 & .20 & .30 \\
\hline
\end{tabular}

* significance at the $10 \%$ level; ** significance at the $5 \%$ level; *** significance at the $1 \%$ level

presence of physical and social disturbance, presence of dark corners), and they are also well connected to the urban fabric, accessible but relatively small, and surrounded by more affluent neighbourhoods (close to bicycle storage, restaurants).

Similar pattern is found for overall violence (Table 1), with the exception that stations with high rates tend to be located more in the outskirts, possibly in regional centres, close to shopping malls. For thefts and robberies (and total crimes), the conditions (indicated by significance of Factors 1,2 and 3) found at stations located in inner city areas are better predictors of these property crimes. For total crime, factors reflecting internal features of the stations, their locations and surroundings explain around $30 \%$ of the variation of total crime in the São Paulo metro; this percentage varies by offence type, and for the model of sexual crimes against women, it explains a quarter of the variation of the dependent variable.

\section{Current practices against sexual crimes against women in transit}

The São Paulo metro develops security strategies with the purpose of curbing crime on its premises. The programme 'You are not alone' (Você não está sozinha) that started in 2014 is devoted to combat the practice of sexual harassment and/or sexual violence 
in the metro. The programme has several areas of action, including some that follow situational crime prevention principles, such as earmarking resources for CCTV and security personnel, training of personnel, providing information over a longer period of time (e.g. a video about the programme that has been showing in each carriage since 2015) to empower women to report and to engage staff and passengers to intervene and support victims, thus transforming passengers into 'capable guardians' (Fig. 4). All these initiatives have so far received mixed reactions.

An issue that has been a source of criticism of the metro's campaign is that it limited in creating incentives for sexual abuse detection, and by doing so, that it is neglecting victims' needs and support. The second is that it relies heavily on users to report these offences, but very little is suggested about the company's role after the event has already happened. It has been suggested that the campaign takes away the metro's responsibility and moves it to victims and passengers to deal with the problem. According to the metro company:

there are over a thousand agents trained to act for the benefit of all passengers, be they men or women, seniors, adults or children (Metrô 2017)

Yet not much is known about the distribution of trained guards and other personal and their practices. Newspapers show examples that the post-complaint support from the company may be lacking. If victims are not helped in real time (as illustrated in the next section), it may be difficult to expect any long-term effect of the campaign:

It was crowded, but there was room to be relatively far away. I was surprised that he was behind me... I sent a message to the sms-service and to my surprise I received 'a standard message' from them ... and I did not get any support from the service at all (student, on the way to the university).

On the other hand, a positive impact of the campaign has certainly been the increase in reporting and protesting (Fig. 3b). According to Soares (2015), a survey that was performed by the metro itself shows that $83 \%$ of respondents spontaneously recalled

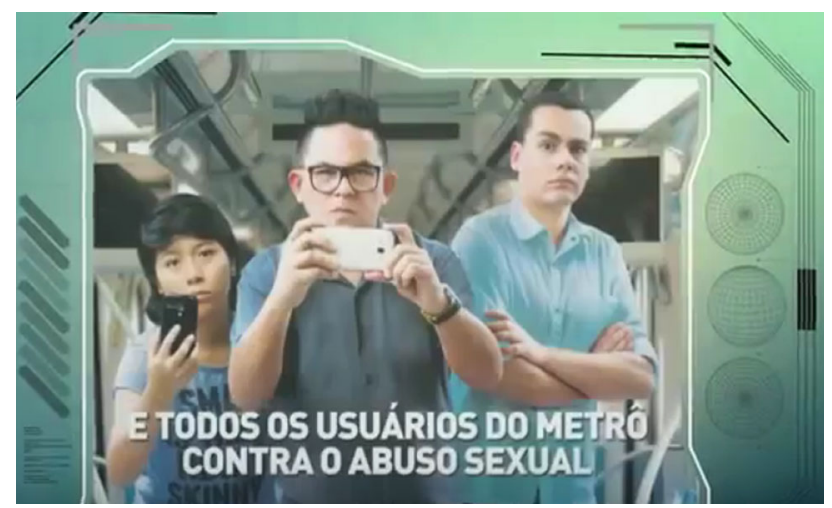

Fig. 4 Whose responsibility? Photograph from metro campaign against sexual abuse: 'All metro users against sexual abuse' (E todos os usuários do metrô contra o abuso sexual) 
the campaign; $82 \%$ believed that by reporting, cases of abuse should decrease; and two-thirds of interviewed users who assessed the campaign felt more at ease in personally reporting cases of sexual abuse after the campaign.

\section{Discussion of results}

Crime and poor perceived safety in public transportation are crucial issues which disproportionately affect women worldwide (Peters 2013). Sexual crimes against women in transit constitute a large share of these crimes. In the São Paulo metro, $12 \%$ of total reported crime incidents constitute cases of, for example, staring, touching, groping, ejaculation, exposing genitalia and full rape-crimes that are highly underreported. This type of offence concentrates at inner city stations of São Paulo, particularly on the Red Line. Typical but not exclusive to large cities of the Global South, overcrowding is an important facilitator of this offence. Paths of millions of people overlap in these transportation nodes (Brantingham and Brantingham 1995), making some of them offenders and others, victims. Most cases happen on weekdays when people are going to or returning from work, corresponding well with people's daily routine activities (Cohen and Felson 1979).

Modelling results also confirm this offence's concentrated pattern at São Paulo inner city stations. Modelling results also show distinct patterns for property (city centre dynamics) and violent crimes (smaller stations). Although these findings are new, they are not exceptional when compared with findings from studies elsewhere (Ceccato 2013; LaVigne 1997; Newton et al. 2015; Smith 2008). Important to note is that since data from the São Paulo metro suffer from relatively low reporting practices, results should be considered with care. As for other types of crimes, sexual crimes against women in São Paulo metro are associated with particular features of the stations as well as the stations' locations and surroundings. This offence pattern is better explained by the criminogenic conditions found also for violence at central stations (e.g. presence of physical and social disturbance, presence of dark corners, relatively large numbers of CCTVs and metro personnel), stations well connected to the urban fabric, and surrounded by more affluent neighbourhoods.

In a methodological note, this study also illustrates the potentialities of combining data from different sources on the stations and surrounding areas into a single geographical framework using GIS. In particular, the study shows the potential of using Google Street View as a source of information about the urban environment when data collection in the field is not an alternative. Although information cannot be collected inside the stations, Google Street View shows an enormous potential for checking the outdoor environment around the subway stations, at least during day time.

In recent years, the metro has implemented a campaign to combat sexual harassment and/or sexual violence, which has so far been successful in increasing the number of reported cases (Soares 2015), but may be limited in improving women's safety. A problem is that the programme has highly relied on reporting to those 'who are around', which means cases are underreported at smaller stations, since personnel tend to be concentrated at larger stations. The deficiency of the reporting system in immediately 
providing a response is also worrying since it will certainly affect women's willingness to report an event in the future-which means that the problem persists.

\section{Conclusions, limitations and implications}

Any type of prevention measure to combat sexual harassment and/or sexual violence in the metro must consider the fact that these offences show distinct temporal peaks that correspond to people's daily routine activities. Spatially, the distinct pattern by type of offence and station as illustrated in this study calls for safety interventions that are adapted to the types of stations (indoor and outdoor environments) but also their specific neighbourhoods and city contexts. In São Paulo, for sexual harassment and violence against women in transit, for example, a partial solution to the problem is to create special programmes focused on central stations, particularly on the Red Line and during peak hours. A solution is to implement in the metro system joint initiatives directed to women's safety together with the so-called Delegacias das Mulheres (women's police stations), which are specialised units within the police attended by all female staff. These women's police stations were established in late 1980s in São Paulo and they still are considered one of the most important models to combat violence against women in the juridical field in Brazil. Moreover, it should be noticed that women may not want to go to the police, be interrogated, go to court, be crossexamined (it can time consuming and traumatic). Therefore, there must be other avenues women can take than reporting, such as NGOs, women's groups, as there might be more support in these types of initiatives than the police can offer.

It would be naïve to believe that tackling the problem of central stations is enough to reduce the problem overall. Women's safety in the São Paulo metro reflects a more fundamental problem that is not properly tackled, namely ensuring individuals' rights to public transportation. As it is now, the metro system runs over capacity; buses, vans together with commuting trains and metro are not enough to move people around. Most passengers are 'transit captives' (Yu and Smith 2014), which means that they do not have any other reasonable means, apart from public transportation, to get from one place to another. Yet, in order to avoid the safety problem, women change routes, quit jobs or define other strategies to cope with unsafe transit environments.

In the future, 'a whole journey approach' must be in place to facilitate a better understanding of the barriers when tackling problems of women's safety (Smith 2008). A limitation of this current study is that the analysis has been restricted to the situational conditions of crime at and surrounding the metro stations. In practice, 'a whole journey approach' means that one must highlight aspects of the transit journey for female passengers, which requires combined attention from transportation providers, local governmental authorities (including police departments), policy makers and other stakeholders. Fundamental in this process is to incorporate women's voices and views into transport services. Assuming that passengers have access to the technology, the use of ICT and social media can be a faster way of informing passengers and reporting problems. Coupled to crime detection, a basic requirement is having systems to support victims in the metro that can give assistance to women after an incident has already happened. 
A limitation of this study is that it has focused on women's victimisation only, and therefore did not address unwanted sexual behaviour on public transport against other groups, in particular those who are potentially more targeted (e.g. the LGBTQ community). There has been evidence that gay men and transgendered persons are often targets of harassment and violence in the São Paulo metro (see e.g. UOL 2014) but also elsewhere (Gekoski et al. 2015).

The goal is already set. For a city like São Paulo to be 'sustainable', it needs to fulfil the mobility needs of its citizens_-regardless of age, gender, sexual orientation, ethnic background-via an accessible, reliable and safe transportation system. Despite its limitations, this study has made a contribution to this goal by providing an overview of the problem of sexual harassment and violence against women in transit.

Acknowledgements The authors thank Metrô de São Paulo for providing data for the analysis, in particular Marcelo Borg and Francisco Pelegate. Thanks also go to Erick Tonin for supporting the process of data acquisition. The authors are grateful for the comments provided by the participants of the session "Sexual Victimization in Public Transport: An International Perspective" chaired by Prof Mangai Natajaran at The American Society of Criminology Conference in 2016, in New Orleans, USA.

\section{Appendix 1: 'O Metrô'-the São Paulo metro (65 stations)}

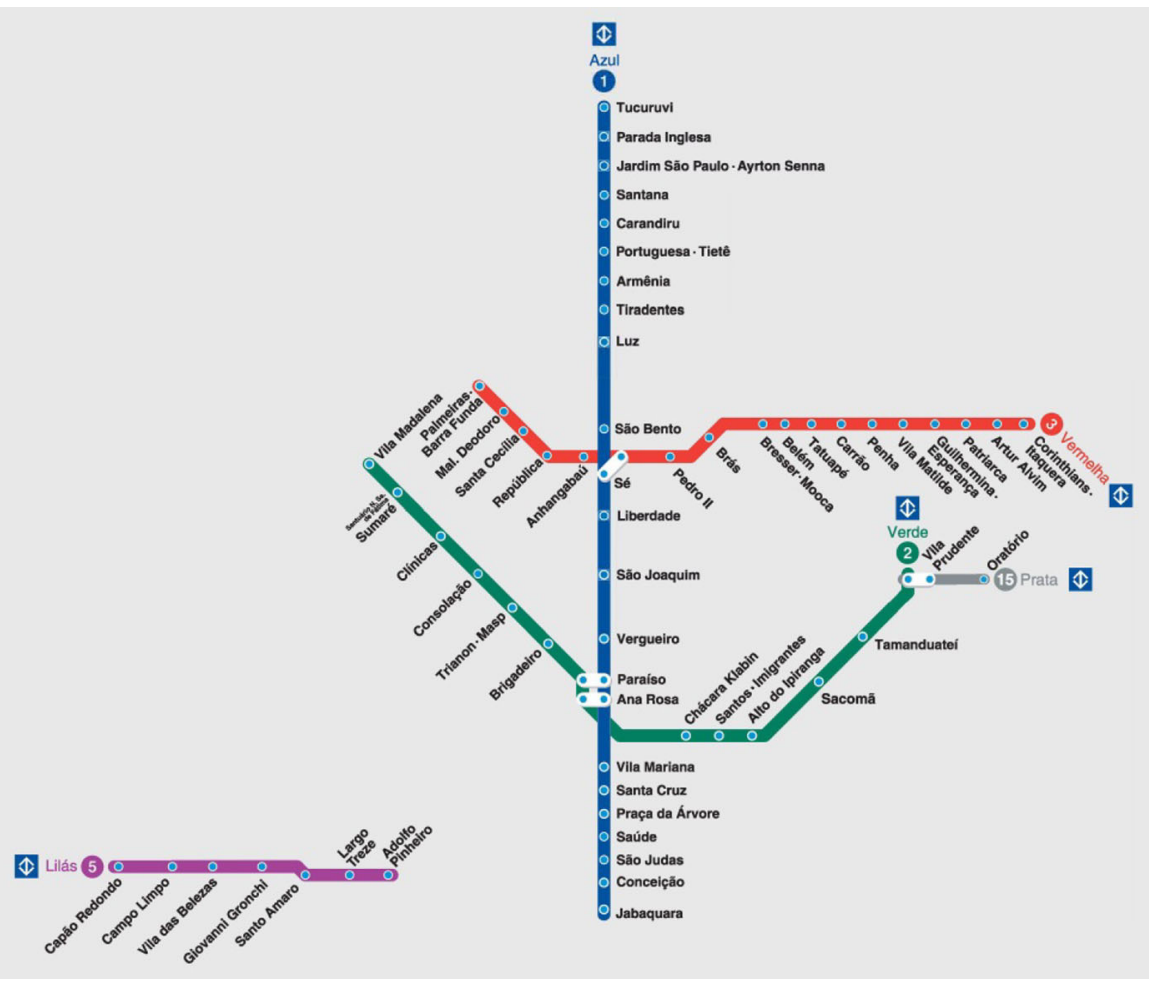




\section{Appendix 2: The database of study (selected variables)}

\begin{tabular}{ll}
\hline Variable description & Source \\
\hline Number of passengers between 7 a.m. and 9 a.m. & Metro company \\
Number of passengers between 5 p.m. and 7 p.m. & Metro company \\
Number of passengers between 10 p.m. and 12 p.m. & Metro company \\
Number of passengers in working day & Metro company \\
Number of employees working to support and maintain the station & Metro company \\
Number of station's security employees & Metro company \\
Visibility from outdoors/indoors & Google Street View \\
Close to one or more public roads & Google Street View \\
Close to one or more bus stops & Google Street View \\
Close to one or more taxi stops & Google Street View \\
Close to one or more green areas (parks, woods) & Google Street View \\
Presence of any litter/any other physical deterioration outside & Google Street View \\
Presence of seats/benches outside & Google Street View \\
Presence of civil guards outside & Google Street View \\
Presence of police outside & Google Street View \\
Presence of bars, restaurants & Google Street View \\
Presence of shopping mall & Google Street View \\
Presence ATM/bank & Google Street View \\
Presence hiding corners/dark corners & Google Street View \\
Presence of large cross section/junctions & Google Street View \\
Cases of detected weapons in the streets & SSP \\
Total population in the area & GeoSampa \\
Total of population receiving minimum salary & GeoSampa \\
Total population in the area up to 5 years of elementary school & GeoSampa \\
Distance to the city centre & Meters \\
Distance to schools & kilometres \\
\hline & \\
\hline
\end{tabular}

\section{References}

Araújo, T. 2016. Metrô de SP Tem Recorde de Assédios Contra Mulheres em 2015. Exame 11 February. http://exame.abril.com.br/brasil/metro-de-sp-tem-recorde-de-assedios-contra-mulheres-em-2015/. Accessed 17 April 2017.

Brantingham, P., and P. Brantingham. 1995. Criminality of place: Crime generators and crime attractors. European Journal on Criminal Policy and Research 3(3): 1-26.

Can, T. 1995. The existence of sexual harassment in China. Chinese Education and Society 28(3): 6-14.

Ceccato, V. 2013. Moving safely: Crime and perceived safety in Stockholm's subway stations. Plymouth: Lexington.

Ceccato, V., and A. Newton. 2015. Safety and security in transit environments: An interdisciplinary approach. Basingstoke: Palgrave.

Ceccato, V., D.J. Wiebe, B. Eshraghi, and K. Vrotsou. 2017. Women's mobility and the situational conditions of rape: Cases reported to hospitals. Journal of Interpersonal Violence. doi:10.1177/ 0886260517699950 . 
Clarke, R.V. 1997. Situational crime prevention: Successful case studies. New York: Harrow and Heston.

Cohen, L.E., and M. Felson. 1979. Social change and crime rate trends: A routine activity approach. American Sociological Review 44(4): 588-608.

Costello, A.B., and J.W. Osborne. 2005. Best practices in exploratory factor analysis: Four recommendations for getting the most from your analysis. Practical Assessment, Research and Evaluation 10(7): 9.

Datafolha. 2014. Termômetro Paulistano-Assédio Sexual Contra as Mulheres. www.datafolha.com.br. Accessed 5 April 2017.

Diógenes, J. 2017. Denúncias de Assédio Sexual em Onibus, Metrô e Trem Sobem 850\% em São Paulo. Estadão 14 March. http://noticias.uol.com.br/ultimas-noticias/agencia-estado/2017/03/14/sao-paulotem-4-registros-de-assedio-sexual-por-semana-no-transporte-publico.htm?cmpid=copiaecola. Accessed 5 April 2017.

Gekoski, A., M. Jacqueline, M.H. Gray, S.E. Horvath, E. Aliye, and J. Adler. 2015. 'What Works' in reducing sexual harassment and sexual offences on public transport nationally and internationally: A rapid evidence assessment. London: British Transport Police and Department for Transport.

Hewitt, A., and E. Beauregard. 2014. Sexual crime and place: The impact of the environmental context on sexual assault outcomes. Journal of Criminal Justice 42(5): 375-383.

JC-Jornal do Comercio 2016. Jovem é Assediada no Metrô do Recife e Suspeito é Detido. Jornal do Comercio September 21. http://jconline.ne10.uol.com.br/canal/cidades/policia/noticia/2016/09/21/ jovem-e-assediada-no-metro-do-recife-e-suspeito-e-detido-253753.php. Accessed 5 April 2017.

LaVigne, N. G. 1997. Visibility and vigilance: Metro's situational approach to preventing subway crime. Washington, DC: National Institute of Justice. https://www.ncjrs.gov/pdffiles/166372.pdf. Accessed 5 April 2017.

Lea, S., E. Silva, and A. Asok. 2017. Women's strategies addressing sexual harassment and assault on public buses in India: An analysis of Crowdsourced data. Crime Prevention and Community Safety (in press).

Levine, N., M. Wachs, and E. Shirazi. 1986. Crime at bus stops: A study of environmental factors. Journal of Architectural and Planning Research 3(4): 339-361.

Levy, J.M., Y. Irvin-Erickson, and N. La Vigne. 2017. A case study of bicycle theft on the Washington DC metrorail system using a routine activities and crime pattern theory framework. Security Journal. doi:10.1057/s41284-017-0096-z.

Loukaitou-Sideris, A. 2012. Safe on the move: The importance of the built environment. In The urban fabric of crime and fear, ed. V. Ceccato, 85-110. Dordrecht: Springer.

Loukaitou-Sideris, A., R. Liggett, and H. Iseki. 2002. The geography of transit crime. Journal of Planning Education and Research 22(2): 135-151.

Madan, M., and M. Nalla. 2015. Sexual harassment in public spaces: Examining gender differences in perceived seriousness and victimization. International Criminal Justice Review 26(2): 80-97.

Metrô-Metrô de São Paulo. 2015. About Companhia Do Metropolitano De São Paulo. São Paulo: The Secretary of Metropolitan Transport. http://www.metro.sp.gov.br/en/metro/about-us/index.aspx. Accessed 5 April 2017.

Metrô-Metrô de São Paulo. 2017. Campanha Contra o Abuso Sexual no Metrô. São Paulo: The Secretary of Metropolitan Transport. http://www.metro.sp.gov.br/metro/marketing-corporativo/ campanhas/campanha-contra-abuso-sexual.aspx. Accessed 5 April 2017.

Mustaine, E.E., R. Tewksbury, and K.M. Stengel. 2006. Social disorganization and residential locations of registered sex offenders: Is this a collateral consequence? Deviant Behavior 27(3): 329-350.

Natarajan, M. 2016. Rapid assessment of "eve teasing" (sexual harassment) of young women during the commute to college in India. Crime Science 5(1): 1-11.

Natarajan, M., R. Clarke, C. Carcach, C. Ponce, E.D. de Sanfeliú, M. Polanco, and M. Shi. 2015. Situational prevention and public transport crime in El salvador. Crime Science 4(29): 1-15.

Newman, O. 1972. Defensible space-Crime prevention through urban design. New York: Collier Books.

Newton, A., H. Partidge, and A. Gill. 2015. In and around: Identifying predictors of theft within and near to major mass underground transit stations. In Safety and security in transit environments, ed. V. Ceccato, and A. Newton, 99-118. Basingstoke: Palgrave.

Newton, A.D., S.D. Johnson, and K.J. Bowers. 2004. Crime on bus routes: An evaluation of a safer travel initiative. Policing: An International Journal of Police Strategies and Management 27(3): 302-319.

Peters, D. 2013. Gender and sustainable urban mobility. https://unhabitat.org/wp-ontent/uploads/2013/ 06/GRHS.2013.Thematic.Gender.pdf. Accessed 19 May 2017. 
Seedat, M., S. MacKenzie, and D. Mohan. 2006. The phenomenology of being a female pedestrian in an African and an Asian city: A qualitative investigation. Transportation Research Part F: Traffic Psychology and Behaviour 9(2): 139-153.

Sham, R., N. Omar, and D.W. Amat. 2013. Women and crime in central business district area. Journal of Asian Behavioural Studies 3(11): 1-12.

Shaw, C.R., and H.D. McKay. 1942. Juvenile delinquency and urban areas. Chicago: University of Chicago Press.

Smith, M.J. 2008. Addressing the security needs of women passengers on public transport. Security Journal 21(1): 117-133.

Soares, N. 2015. Campanha do Metrô de SP Contra Abuso Sexual Tem 79\% de Aprovação. http:// emais.estadao.com.br/blogs/nana-soares/campanha-do-metro-de-sp-contra-abuso-sexual-tem-79de-aprovacao/. Accessed 5 April 2017.

Souza, M. and Valle, C. 2017. Denúncias de Abuso Sexual Crescem no Metrô de SP; Veja os Horários Mais Perigosos. UOL Notícias. December 1. http://noticias.uol.com.br/cotidiano/ultimas-noticias/ 2017/01/12/em-sp-casos-reportados-de-abuso-sexual-em-trem-ou-metro-se-concentram-as-8h.htm. Accessed 5 April 2017.

Uittenbogaard, A. 2015. An assessment of guardianship opportunities as provided by environments of transit stations. In Safety and security in transit environments, ed. V. Ceccato, and A. Newton, 56-75. Basingstoke: Palgrave.

UOL. 2014. Casal Homossexual é Espancado por 15 Homens no Metrô de São Paulo. December 11. http://noticias.uol.com.br/cotidiano/ultimas-noticias/2014/11/12/casal-homossexual-e-espancado-por15-homens-no-metro-de-sao-paulo.htm?cmpid=copiaecola. Accessed 5 April 2017.

Valle, C. and Bottini Filho, L. 2014. Roubos e Furtos Quase Dobram no Metrô e CPTM. Estadao 23 January. http://sao-paulo.estadao.com.br/noticias/geral,roubos-e-furtos-quase-dobram-no-metro-ecptm-imp-,1121742. Accessed 5 April 2017.

Yu, S.V., and M.J. Smith. 2014. Commuters using public transit in New York City: Using area-level data to identify neighbourhoods with vulnerable riders. Security Journal 27(2): 194-209. 